\title{
Paper Histological Study of Lavatera Maritima in the Region of Marsa Ben Mehidi
}

\author{
Ghalem Sarra*, Hassani Faiçal \\ Email address: \\ sarah.ghalem $a$ outlook.com (G. Sarra), faicalhassani@yahoo.fr (H. Faiçal) \\ ${ }^{*}$ Corresponding author
}

Laboratory of Ecology and Management of Natural Ecosystems, Faculty SNV.STU-University of Tlemcen, Tlemcen, Algeria

To cite this article:

Ghalem Sarra, Hassani Faiçal. Paper Histological Study of Lavatera Maritima in the Region of Marsa Ben Mehidi. American Journal of Science, Engineering and Technology. Vol. 4, No. 2, 2019, pp. 30-33. doi: 10.11648/j.ajset.20190402.11

Received: February 15, 2019; Accepted: May 15, 2019; Published: July 23, 2019

\begin{abstract}
The present work concerns a self-ecological study of Lavatera maritima (malvaceae) in the region of Marsa benmehidi, for this study we are based on histological criteria. Plant organisms and especially flowering plants are distinguished from most animal organisms by remarkable characters. These plants are practically immobile and fixed in the soil. As a result, they depend on the environment around them. This study aims to explore the structure of living organisms, the constitutive and functional relationships between their elements, as well as the renewal of tissues. It allowed us to know the tissues, organs following the leaf, the stem, the root and the different tissues such as xylem, phloem... etc.
\end{abstract}

Keywords: Lavatera Maritima, Malvacea, Marsa Ben Mehidi, Histological

\section{Introduction}

The vegetation of Tlemcen is a good example of a study of diversity plant and, above all, an interesting synthesis of the natural dynamics of ecosystems, from the littoral to the steppes [1].

The ligneous plan of a species, the grouping and the nature of the different elements constitutive of its wood; vessels, woody rays, fibers, parenchyma whose arrangement remains constant for a given species, allowing the characterization of woody species [2].

Indeed, several researches have been carried out on the autoecology of different plant species, histology and more particularly on histometry, mention may be made of the work [3-6].

Plant histology is the part of plant biology that studies the microscopic structure of plant tissues. This science provides a basic structure for the study of physiology [7].

Histology is the study of tissue cell clusters [8]. The histological study made at the level of leaves, stems, roots Lavatera maritima allows us to analyze accurately and precisely its structures, and consequently to deduce the explanation of certain histological modifications, from this study we will try to draw from general laws concerning the disposition of tissues in plant organs. The methodology of plant histology is not fundamentally different from that of animal histology. The basic technique usually involves fixing the samples and then hardening or inclusion in paraffin or plastic substances, sections by microtomy and then topographic or topographic stains when looking for an overview, or specific when you want to characterize certain structures electively. We will say that a tissue is the set of cells similar to the points of the morphological and functional view [9].

There are three tissue systems and their presence in the root, the stem and leaf reflects both the fundamental similarity between the organs of the plant and the continuity of the organism.

The three systems are:

1. Fundamental tissues of three types: the parenchyma, the collenchyme and the sclerenchyma;

2. Conductive fabrics including xylem and phloem;

3. Protective tissues represented by the epidermis, external protective envelope of the primary structure and then peridermally in the parts of the body that possess secondary thickening [10].

The anatomical sections concerned the leaves (scales or articules) of the branches, the stems and the fresh roots by a number of ten individuals taken from each station applying the technique of freehand cuts [11].

The histological study of lavatera maritima we allowed to 
accurately analyze the different structures and to draw the general characteristics concerning the disposition of tissues in the organs of the plant.

\section{Material and Methods}

Stresses that in all modern scientific research, the question of methods plays a vital role and must be the subject of a very serious examination. Its nature and quality methods that alone can guarantee the strength and value of the results obtained. [12].

When it comes to plant biology, any method or interpretation error can move us away from the goal indefinitely.

We were seduced and captivated by the quality of the work done [13], during his numerous interventions on the Microskopia forum since 2004, while specifying it has a very simple equipment, within the reach of everyone.

For our case, the histological study requires the experimental device, consisting of a list materials and a set of solutions [14].

\section{Results and Observation}

\subsection{At the Root Level}

The root is the underground organ of a plant used to fix it on the ground and to draw water from it.

Roots are often the seat of symbiosis with bacteria and soil fungi, especially for nitrogen metabolism. The roots may have adaptations to facilitate the development of the plant in a particular environment [15].

1. The observation of a cut made at the root shows the presence of the following tissues (from the outside to the inside):

2. Epidermis: A single row of living cells (layer stratum) of forms Thin-wall and cellulosic-walled variables prolonged by often branched, absorbent hairs. This tissue is called piliferous seat plays an important role in the protection of the root.

3. Cortical parenchyma: This tissue is thick Figure 2 representation of the different types of tissues at the root level. consisting of large cells of color Green with irregular shapes. Its large surface increases the absorption of water and minerals. He plays a role of reserve, he stores the elaborated matters.

4. Sclerenchyma: It is formed of cells in more or less rounded clusters.

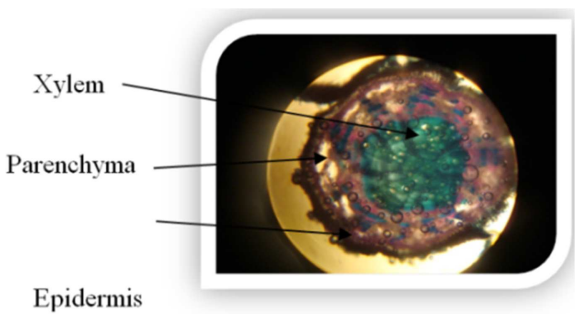

GR: 3,2

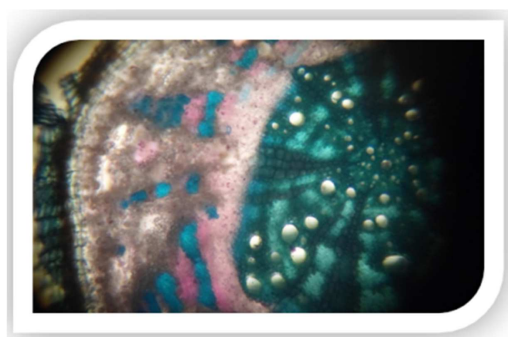

GR: 10

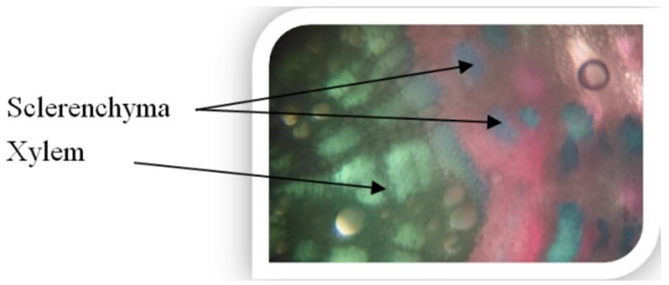

GR: 40

Figure 1. Cross sections of part of the root.

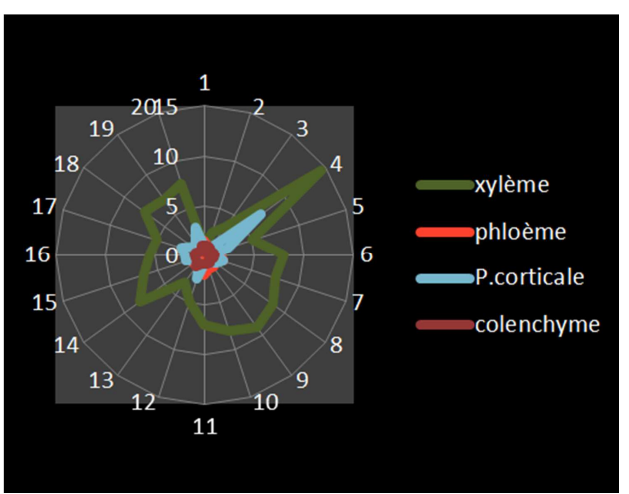

Figure 2. Representation of the different types of tissues at the root level.

The figure above represents the thickness (different in thickness) of each tissue ie phloem, xylem, epidermis, collenchyme and cortical parenchyma.

It appears from the figure above that: The xylem dominates by a very large thickness and crushes the other tissues, followed by the cortical parenchyma, then the phloem and finally the collenchyme.

\subsection{At the Stem Level}

The observation of his transverse sections of the stem of lavatera maritima under an optical microscope allowed him to highlight the following tissues: an epidermis, xylem, phloem, medullary parenchyma and a cortical parenchyma.

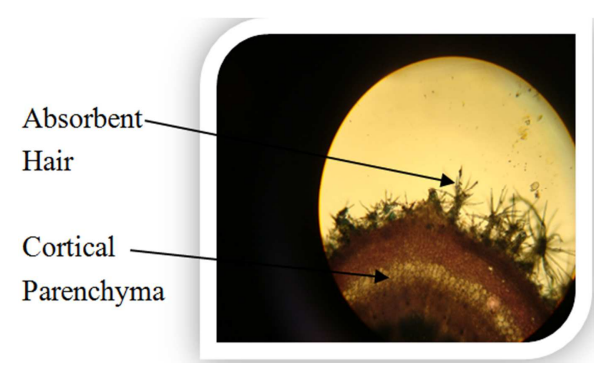

GR: 10 


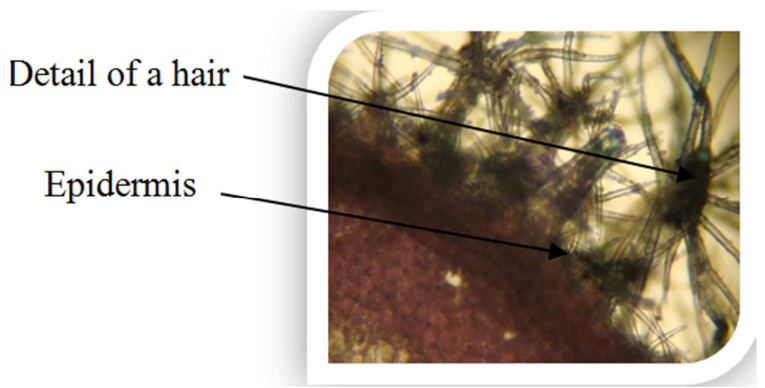

GR: 40

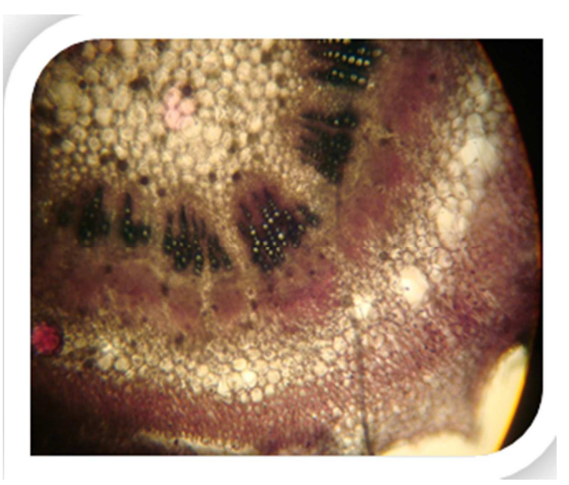

Figure 3. Cross sections of a part of the stem.

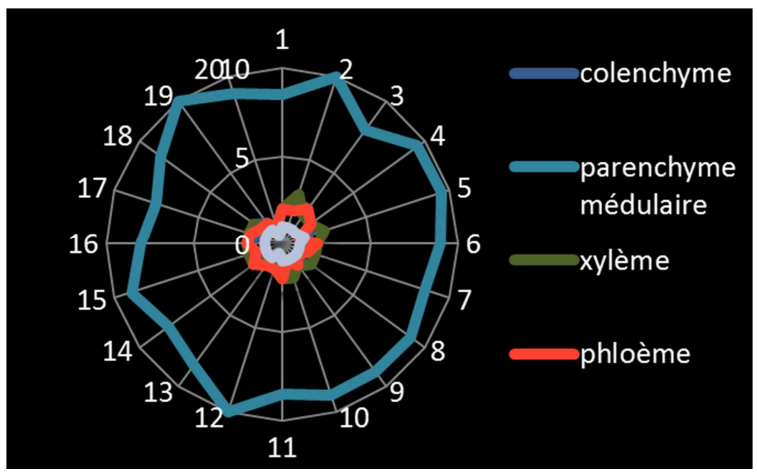

Figure 4. Representation of the different types of tissues at the stem level.

Figure 4 shows that the medullary parenchyma is the thickest tissue.

The phloem and the xylem are about the same thickness.

The collenchyma and lacenchy parenchyma are crushed due to their small thickness

\subsection{At the Leaf Level}

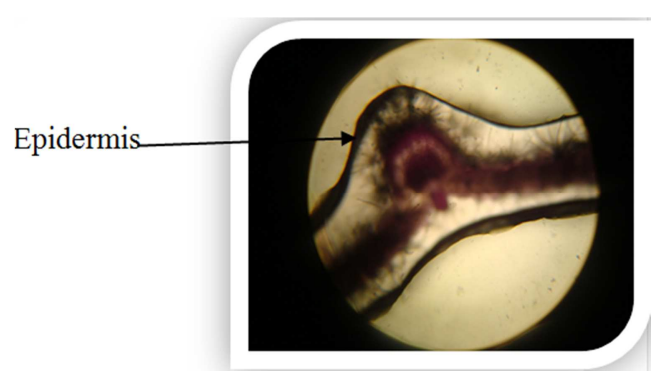

GR: 10

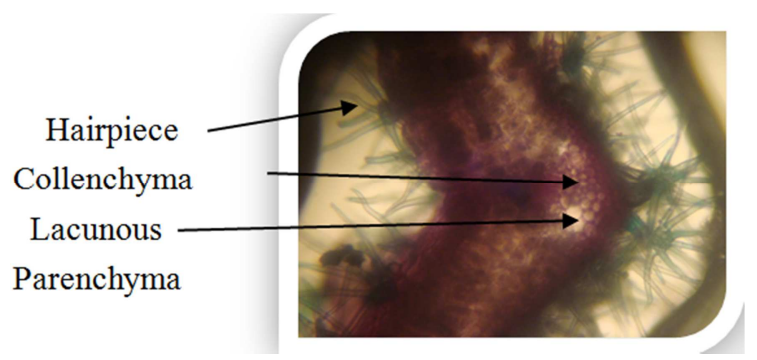

GR: 40

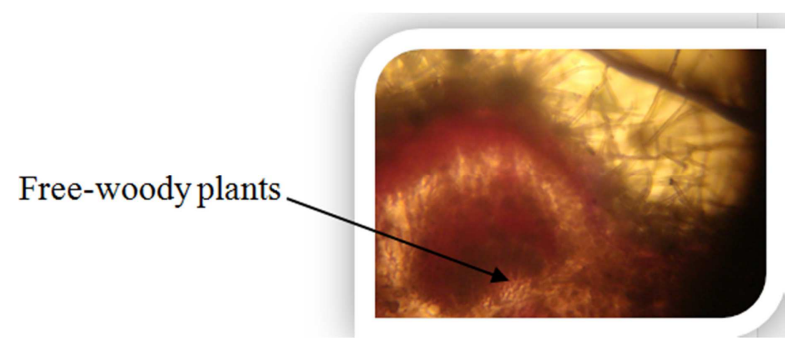

GR: 40

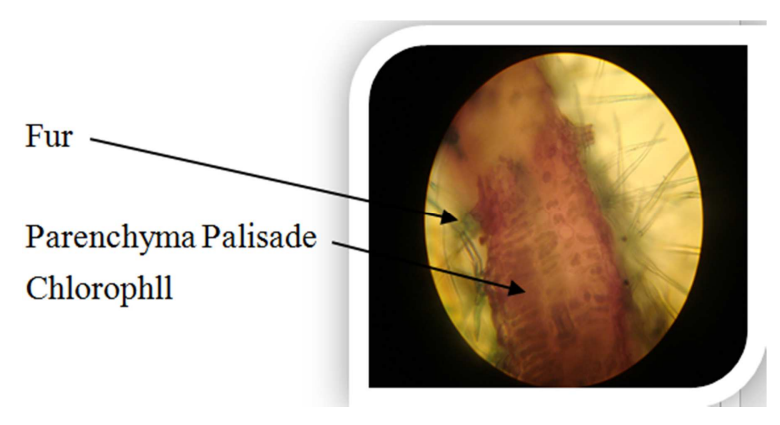

GR: 40

Figure 5. Cross sections of a part of the leaf

The figure below represents the thickness (difference in thickness) of each tissue namely the phloem, the xylem, the epidermis, the palissadic parenchyma.

It can be seen from Figure $\mathrm{N}^{\circ} 06$. That the palisade parenchyma is the thickest, alternating between the xylem and the lacunous parenchyma.

In the last position the phloem and the epidermis.

Most epidermal cells form a compact unit that provides the plant's organs with effective mechanical protection against evapotranspiration.

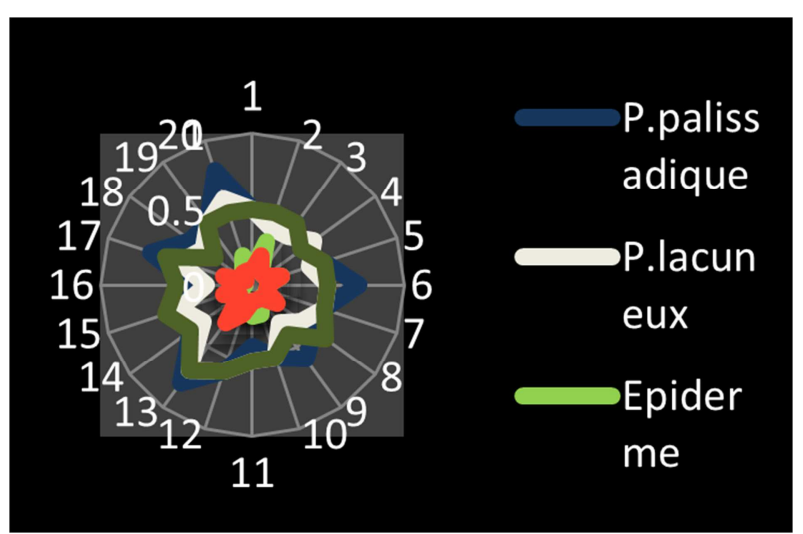

Figure 6. Representation of the different types of tissues at leaf level. 


\section{Conclusion}

In the organs of plants, as in those of animals, the cells are divided into specialized populations or tissues. It is therefore a functional whole that realizes a division of physiological work [16].

The results reported in this study show:

1. Difference in tissue thickness from one organ to another and from one station to another. The dimensions of the tissues provide information on the physiological state of the plant and the conditions in which the plant evolves (salt and water stress, etc.). Chlorophyllian palissadic parenchyma more developed in leaves. This can be justified by the quasi substitution of the sheet in its assimilating role.

2. Presence of collenchyme support tissues at the root and stem that contribute to plant rigidity and strength.

\section{References}

[1] STAMBOUli H., BOUAZZA M. et THINON M., 2009 -La diversité floristique que la végétation psammophyle de la région de Tlemcen (Nord-ouest Algérie), Elsevier, v I. III; Prn: 29/ 04/ 2009; 1-9p

[2] VENET, J. 1986 - 6ème Edition revue par Keller. ENGREF. Nancy. France. 308p.

[3] BOUAZZA M., 1991 - Etude phytoécologique de la steppe a Stipa tenassicima L., et à Lygeum spartum L. au Sud de Sebdou (Oraine-Algérie). Thése de doctorat. Univ Aix-Marseille. 119p.

[4] AMARA M; 2008 - Contribution à l'étude de Pistacia atlantica Desf. Dans le Nord-Ouet Algérien: Aspects écologiques et cartographie. Mém. Mag. Univ Tlemcen 150 p. + carte.
[5] HENAOUI S et BOUAZZA M., 2013- Contribution a une etude morpho HistométriquedeCistusladaniferus subsp. Aricanus dans la region de Tlemcen (Algerie occidentale). Univ. Abou baker Belkaid-Tlemcen.

[6] BESTAOUI KH., 2001 - Contribution à une étude syntaxonomique et écologique des Matorrals de la région de Tlemcen. Th. Magistère en biologie. Ecol. Vég. Dép. Bio. Fac. Sci. Univ. Abou Bakr Belkaïd. Tlemcen. 184 p + annexes.

[7] Leesson C. R. et Leesson T. S., 1980 - Histologie. 2ème édition. Masson. Pp: 4-5.

[8] CRETE P., 1965-Le bioclimat méditerranéen, caractères généraux, modes de classification. Végétation, 34: 1-20.

[9] Hould R. Histologie descriptive et éléments d'histopathologie. Décarie éditeurs. Montréal. P. 148- 151. 1982.

[10] Raven P. H., Johnson G. B., Losos J. B., Singer S. S., 2007. Biologie végétale - De boeck-. 2e éd. 733 p.

[11] BERLYN. G. P ET MICSCHE. J. P; 1976 - Botanical microtchnique and cytochmistry, The Iowa state university, Press Ames Iowa. $450 \mathrm{p}$.

[12] BERTRAND A., 2009 - Home. Documentaire scientifique.

[13] CHRISTIAN AUBERT; 2004 - Interventions sur le site du forum Microskopia depuis 2004.www.web-artisaus.com/microscopie-consulté le 24 mars 2011.

[14] BARKA F- Etude des groupements à matorral dans le littoral de la région de Tlemcen. Aspects phytoécologiques et cartographie. P: 167.

[15] BOUAYED; 2017 - Etude des groupements à Withania frutescens (Panquy, 1825) (Solanacées) dans la région de Tlemcen, Algérie occidentale. P. 272.

[16] KEBBAS Y., 2016 - Impact de l'exposition sur la croissance de Withania frutescens (solanacées) dans le Nord-ouest algérien. $135 \mathrm{p}$. 